\title{
The utilisation of the Internet to market small tourism businesses
}

\author{
R. Elliott* \\ Department of Management, Rhodes University. PO Box 94, \\ Grahamstown 6140, Republic of South Africa \\ R.Elliott@ru.ac.za \\ C. Boshoff \\ Department of Business Management, Nelson Mandela Metropolitan University \\ PO Box 1600, Port Elizabeth 6000, Republic of South Africa \\ Christo.Boshoff@nmmu.ac.za
}

Received June 2005

\begin{abstract}
The tourism sector has been identified as an industry that has the potential to make a substantial contribution to the growth of the South African economy. The majority of tourism ventures are, however, small businesses, which differ from their larger counterparts not only in terms of size, but also in regard to access to resources and marketing expertise. Not surprisingly, one of the issues identified as preventing this sector from reaching its full potential is access to markets. The Internet has been identified as tool which may assist small businesses in both their global and domestic marketing.

The focus of this study was to identify the factors specific to the Internet (rather than the technology per se or organisational factors) driving the success of the use of the Internet for marketing purposes in small businesses operating in the tourism sector in South Africa. If these factors can be identified and their relative influence on Internet marketing success be determined, it will allow small tourism businesses utilise the capabilities of the Internet more effectively.
\end{abstract}

The results indicate that having a product champion in the business, having a network of effective alliances, a high level of owner-manager involvement in the Internet marketing strategy as well as a clear owner-manager vision are important to the successful use of the Internet for the marketing of small tourism businesses in South Africa.

*To whom all correspondence should be addressed.

\section{Introduction}

In the global economy small businesses are playing a critical role in reducing unemployment, penetrating new markets and generally growing national economies. It follows that small businesses represent an important vehicle for addressing the challenges of job creation, economic development and social development in South Africa (South Africa. Department of Trade and Industry, 1995; United States. Small Business Administration, 2004). The majority of tourism ventures are small businesses and tourism has likewise been identified as one of the catalysts for growth in the South African economy over the next two decades (South Africa. Department of Environmental Affairs \& Tourism, 1996 and 1998). It has been pointed out, however, that tourism is an under-exploited sector with considerable potential for expansion (WTTC, 2002), particularly given the high labour absorption capacity of small businesses. The growth in numbers employed by small businesses is greater than the growth in the contribution of these enterprises to the country's Gross Domestic Product (GDP). For example, in 2001, the increase in people employed by small businesses was 1.5 times the growth in the contribution of these entities to GDP (Ntsika, 2002).
The importance of tourism to the South African economy is illustrated by the latest estimates from the World Travel and Tourism Council (WTTC), which show that the travel and tourism industry was expected to contribute 2,9 percent to GDP in 2003, rising to 3,6 percent by 2013. The broader travel and tourism economy was expected to contribute 7,3 percent to GDP in 2003, growing to 8,8 percent by 2013. In terms of jobs, it was estimated that in 2003 , the travel and tourism industry accounted for 491741 jobs or 2,9 percent of total employment and by 2013 this is anticipated to increase to 751100 jobs or 3,7 percent of the total number of people employed. The total number of jobs in the broader travel and tourism economy was estimated as 1118530 jobs, 6,6 percent of total employment, and by 2013 this is forecast to escalate to 1650140 jobs or 8,2 percent of total employment (WTTC, 2003).

In spite of these impressive figures, a WTTC (2002) report criticised the progress being made in South Africa as being unsatisfactory and not accomplishing the targets set by the WTTC in 1996. What the report found particularly disappointing was the failure of the tourism sector to create jobs and develop small businesses (WTTC, 2002).

Small businesses, particularly in the tourism sector, view the lack of market access and the inability to sell their goods 
and services as the major obstacles inhibiting their growth and proliferation. This perception is corroborated by studies in South Africa and internationally which view market access as a critical factor in business growth (South Africa. Department of Trade and Industry, 1995). Although all businesses face the challenge of marketing in a global economy (Graham, 1999), small businesses (defined in this study as firms that have fewer than 100 employees) in South Africa face a wider range of constraints and problems and are less able to address the challenges facing them than big business.

One way of prevailing over the marketing challenges faced by small businesses is to use the Internet. It is argued that the Internet allows access to diverse markets irrespective of the size of the business (Haynes, Becherer \& Helms, 1998; Vargha \& Pettigrew, 2001), although the extent of this impact is not clear (Porter, 2001; Kimiloğlu, 2004). Nevertheless, the diffusion of the Internet has fundamentally changed the communication as well as the business paradigms of the world (Hoffman \& Novak, 1996). It has allowed new models of commercial interaction to develop as businesses and consumers participate in the electronic marketplace (Clinton \& Gore, 1997). As a result many businesses compete in two worlds, the traditional marketplace of physical resources (often referred to as a bricks-and-mortar environment) and a virtual world of information, also known as the marketspace (Rayport \& Sviokla, 1995). In the future, in many business sectors, success will be determined by activities in both the real world as well as in the virtual world (Weiber \& Kollmann, 1998).

The marketspace has given rise to the world of electronic commerce (Rayport \& Sviokla, 1995), which allows small businesses to start new businesses more easily and with smaller up-front investment requirements, by accessing the Internet's worldwide network of users (Clinton \& Gore, 1997). Both large and small businesses are embracing the Web to communicate with current and potential customers abroad through the Internet with the same cost and ease as within their countries (Hoffman \& Novak, 1996). In other words, the Internet is a cost-effective medium which small South African tourism businesses can realistically use to market their businesses both locally and internationally.

\section{Problem statement and objectives}

Despite the potential of the Internet as a business and marketing tool, successfully harnessing this medium is proving elusive (Elliott, 1997; Hoffman \& Novak, 1996; Hoffman, Novak \& Chatterjee, 1995). Although there are vast opportunities for businesses on the Internet, the majority of such undertakings do not make a profit as entrepreneurs do not properly understand the drivers of electronic commerce (Remenyi, 2000). This poor grasp of the Internet as a business tool has been corroborated by the failure of many dot com ventures (Hof, 2000). In fairness to those early Internet-based ventures it must be pointed out that at that time, as is still the case today, very little empirical evidence exists on which to base sound business decisions. Computer mediated environments like the Internet are unique and very different from other physical windows of opportunity (Elliott, 1997; Lee, Tan \& Lim, 2000; Turban, Lee, King \& Chung, 2000).

As with all South African small enterprises, small tourism businesses also face the problem of access to markets (Ntsika, 1998; Ntsika, 2002). The Internet, with its ability to reach broad and diverse markets at a very low marginal cost (Arthur, 1996; Carr, 2000) has the potential to contribute to the growth of this sector. However, due to the dearth of empirical studies of the successful use of the Internet in the tourism sector they also are limited in their access to 'best practice'.

Against this backdrop, it is important to identify the factors that influence successful Internet marketing in small tourism businesses. The primary objective of this study was to investigate and empirically test the possible influences and relationships between the various independent variables and the dependent variable, namely the Perceived success of Internet marketing within the tourism industry. The focus of this study was to identify the factors specific to the Internet (rather than the technology per se or organisational factors) driving the success of the use of the Internet for marketing in small businesses operating in the tourism sector in South Africa.

\section{The factors influencing internet marketing success}

Much of the literature about Internet marketing is either anecdotal in nature, merely conceptual or based on case studies. In addition, some authors argue that the use of the Internet for marketing is an innovation (e.g. Bengtsson, Boter \& Vanyushyn, 2003; Mehrtens, Cragg \& Mills, 2001) and that the research in respect of the adoption and implementation of innovations, particularly information technology (IT), are germane to the study of the use of the Internet for marketing.

The limited published quantitative research has predominately taken the form of surveys about the use of the Internet by consumers. This study is different in the sense that an attempt is made to identify the determinants of successful Internet marketing for South African small tourism businesses and then to empirically assess the validity of the model.

The factors (independent variables) considered in this study are those that are associated with the 'implementation' or use of the Internet as a business/marketing tool, rather than any organisational issues. The Internet-related factors identified and empirically evaluated in this study are (a) the owner-manager of the tourism business acting as product champion: (b) owner-manager knowledge; (c) alliances, (d) trust; and (e) owner-manager involvement.

\section{Owner-manager as product champion}

Product champions are the people who recognise the potential of a particular project and take the necessary action to implement the innovation. Although many of the issues surrounding the implementation of an innovation in a large business may not be relevant for small businesses, one area 
of overlap is the enthusiasm of the product champion (Markham \& Aiman-Smith, 2001).

The embracing of the Internet by owner-managers as an important medium to achieve organisational goals is a critical factor in its adoption and successful utilisation (Bengtsson, Boter \& Vanyushyn, 2003; Mehrtens, Cragg \& Mills, 2001; Stansfield \& Grant, 2003; Thong \& Yap, 1995). It follows that if Internet marketing is to be successful in small tourism businesses, the owner-manager should act as a product champion in respect of this initiative. Indeed, research (Bengtsson, Boter \& Vanyushyn, 2003) suggests that a product champion in respect of use of the Internet for marketing may be more important for small and medium sized businesses than for large businesses.

The importance of a product champion for the successful implementation of a new innovation cannot be questioned (Cragg \& King, 1993; Ettlie, Bridges \& O’Keefe, 1984) and the Internet is indeed one of the most significant new innovations of our time (Bengtsson, Boter \& Vanyushyn, 2003; Mehrtens, Cragg \& Mills, 2001). However, Bengtsson, Boter and Vanyushyn, (2003) extend this argument and distinguish between basic and advanced use of the Internet, arguing that the use of the Internet could be both a radical and incremental innovation. The importance of this distinction is that greater top management support is required for radical innovations (Ettlie, Bridges \& O'Keefe, 1984; McDermott \& O' Connor, 2002). It is argued that the importance of the owner-manager acting as a product champion is particularly important in small tourism businesses because of the inseparability of production and consumption (Palmer, 2001) and the significant influence of the owner-manager in small businesses (Carson, Gilmore, Cummins, O’Donnell \& Grant, 1998; Gilmore, Carson \& Grant, 2001; Larkin \& Elliott, 2003).

This conclusion is consistent with research done in respect of the successful adoption and implementation of information technology (IT) by small businesses, which found that management/owner enthusiasm in respect of the initiative, is a critical factor in its successful implementation (Cragg \& King, 1993; Cragg \& Zinatelli, 1995; DeLone, 1988; Thong \& Yap, 1995).

Poon and Swatman (1997, 1999) caution, however, that much of the research done in respect of IT systems and small businesses should be regarded with circumspection, because IT systems are mostly internal, whereas the focus of the Internet is on communications between organisations. The Internet, however, has many similarities to electronic data interchange (EDI) and in both cases having a product champion is important (Mehrtens, Cragg \& Mills, 2001; Runge \& Earl, 1988).

We thus argue that having the owner-manager as a product champion in a small tourism business will enhance the chances of successful Internet marketing in small tourism businesses.

In order to act as a product champion, it would be expected that the owner-manager would have a reasonable understanding of the technology (Stansfield \& Grant, 2003), although this would not necessarily consist of formal training (Poon \& Swatman, 1999).

\section{Owner-manager knowledge}

Some level of technical knowledge by the owner-manager has been found to be an important factor in the successful adoption and implementation of information technology systems (Cragg \& King, 1993; Thong \& Yap, 1995), as it has for the Internet (McGowan \& Durkin, 2002; Mehrtens, Cragg \& Mills, 2001).

In order to integrate the Internet as a core tool for marketing, Durkin and McGowan (2001) posit that 'technical ability' is a competency that needs to be acquired by the ownermanager. They argue that this does not necessarily mean that the owner-manager is able to implement all the technical attributes of this technology, but rather that he at least appreciates the fundamental issues pertaining to its management and utilisation. Technical ability, however, did not necessarily presuppose a broader appreciation of the strategic benefits that the Internet could facilitate.

Others argue that innovations such as the Internet require a knowledge that is greater than a general appreciation of the technology (Jones, Hecker \& Holland, 2003; Shane \& Venkataraman, 2000). They seem to believe that the successful implementation of complex innovations (such as the Internet), in addition to a basic understanding of the principles, requires specialised knowledge of how to operate the technology (Rogers, 1995). However, research done by Poon and Swatman (1997) found that the majority of the owners of the small businesses they surveyed had not received formal training in information technology.

The other school of thought believes that the ownermanager of a small tourism business does not necessarily have to have the technical competence to implement the Internet personally, as much of the required knowledge could be sourced from his personal contact network (McGowan, Durkin, Allen, Dougan \& Nixon, 2001). Reality often confirms this contention. A study by Yeung, Shim and Lai (2003), who conducted research into the adoption of ecommerce by small and medium enterprises in Hong Kong, found that 69 percent of businesses with Web sites relied on outside service providers to design and maintain their Web sites. Nevertheless, a reasonable knowledge and understanding of the Internet by the owner-manager of a small business is necessary for the successful implementation of the Internet for marketing (Marshall, Sor \& McKay, 2000; Neveling, 2004; Stansfield \& Grant, 2003 ), as often only the owner-manager appreciates the critical issues in a small business and is in a position to make informed decisions (O'Toole, 2003; Delone, 1988).

It thus appears as if the knowledge that owner-managers of small tourism businesses have of the Internet will be related to the successful use of the Internet for marketing purposes.

\section{Alliances}

Alliances can take a number of forms (Dean \& Holmes, 1997) and include personal contact networks, social 
networks, business networks, industry and marketing networks (Donckels \& Lambrecht, 1997; Gilmore, Carson \& Grant, 2001; Piercy \& Cravens, 1995). A number of terms such as confederations of specialists, networks and alliances are used to describe these cooperative relationships (Piercy $\&$ Cravens, 1995). These inter-personal relationships take on a particular importance for small businesses when utilising the Internet as a marketing tool (Jones, Hecker \& Holland, 2003; McGowan \& Durkin, 2002).

Alliances play a crucial role in small business marketing by reducing uncertainty, facilitating trust and, in so doing, reducing the risk for all the parties (McGowan et al., 2001). These networks are also used by small organisations to access market information (Carson, Cromie, McGowan \& Hill, 1995), as small businesses often do not have the time or resources to buy market information or solicit the services of business consultants (Collinson \& Shaw, 2001). Not only do alliances contribute to the information resources of small businesses, but they also have an influence on its decisionmaking (Collinson \& Shaw, 2001; Hill \& McGowan, 1996).

Thus, because small businesses may lack the specialised knowledge necessary for the successful planning and implementation of Internet technology to achieve their business objectives (Jones, Hecker \& Holland, 2003) cooperative behaviours will expand their knowledge and overcome resource weaknesses (Lado, Boyd \& Hanlon, 1997) in respect of Internet marketing (Hoffman \& Novak, 1997; McGowan \& Durkin, 2002; McGowan et al., 2001; Rayport \& Jaworski, 2001). This is particularly germane for small businesses, as acquiring the resources to utilise the Internet for marketing purposes may be unfeasible (Jones, Hecker \& Holland, 2003).

Besides the cost-effectiveness of using alliances it must be acknowledged that many tourists regard a destination as a combination of all the individual tourism business and attractions (Bennett, 2000; Middleton \& Clarke, 2001). Being involved in an alliance-type arrangement would thus enhance the chances of successful Internet marketing for a small tourism organisation.

\section{Trust}

Although the issue of trust is at the core of e-commerce (Urban, Sultan \& Qualls, 2000), the lack of trust is based on issues of security rather than the lack of interpersonal interaction (Durkan, Durkin \& Gillen, 2003; Hoffman, Novak \& Peralta, 1999). This contention is supported by the research done by Bhatnagar and Ghose (2004) which revealed that consumers were more concerned about areas of potential risk, such as the integrity of information and the reliability of the vendor, than the benefits of transacting.

Security over the Internet is also a concern for small business owner-managers (Vargha \& Pettigrew, 2001) and research done within the South African context by Kritzinger and Du Plessis (2001) found that 78 percent of respondents felt that security was the main issue to be addressed prior to doing business over the Internet and 80 percent felt that the lack of consumer trust was the biggest factor deterring online commerce (Kritzinger \& Du Plessis,
2001). The issue of trust stems from concerns about information privacy with regard to both environmental control and the secondary use of information (Hoffman, Novak \& Peralta, 1999).

Environmental control reflects consumers' confidence in the security of information disclosed online to effect a transaction or initiate a relationship. Concerns about the secondary use of information stem from the application of personal information disclosed during the course of a transaction. Although, a concern about the privacy of information does span the different media types, this concern is far greater (and will constitute a barrier to transactions/relationships) in the virtual media (Hoffman, Novak \& Peralta, 1999).

While the concerns raised by the environmental control issue are probably shared by small tourism businesses and online consumers, views on the secondary use of information diverge between these two role-players. This divergence is compounded by the ease of collecting personal information about the individual and its analysis by way of data mining and data warehousing (Hoffman, Novak \& Peralta, 1999).

The way to achieve trust is to focus on building a cooperative relationship rather than one dominated by the business (Hoffman \& Novak, 1997), which may mean implementing policies that allow consumers to elect not to disclose personal information (Hoffman, Novak \& Peralta, 1999; Urban, Sultan \& Qualls, 2000; Venkatraman, 2000). Although this co-operative relationship should result in greater levels of trust and loyalty (Hoffman, Novak \& Peralta, 1999), security may still be an issue that will obstruct the building of relationships.

Trust is also an important element of relationship marketing (Morgan \& Hunt, 1994), but is particularly challenging in the case of doing business over the Internet where there are few physical cues to engender feelings of trust. Only if customers trust a business, will they be willing to share personal information, which is crucial for being able to build a relationship (Hoffman, Novak \& Peralta, 1999; Reichheld $\&$ Schefter, 2000). This in turn allows the business to customise products for individuals, which in turn leads to greater trust, which should strengthen the relationship (Reichheld \& Schefter, 2000). Although trust is important in building relationships over the Internet, this medium does provide opportunities to build trust (Hart, Doherty \& EllisChadwick, 2000; Reichheld \& Schefter, 2000).

Based on the preceding review we suggest that the absence of trust will negatively impact on the successful use of the Internet for marketing in small tourism organisations.

\section{Owner-manager involvement}

Durkin and McGowan (2001) developed a theoretical model that attempted to describe the role and importance of the Internet on the marketing activities of entrepreneurial businesses. The model is based on the competencies that such a business would need to possess to be able to move from conceptualising the possible utilisation of the Internet 
as a marketing tool to its successful implementation. They argue that the first competency that is required is that the entrepreneur should have a 'vision' of what the Internet can achieve. The second competency was termed 'value', which implies that the owner-manager takes his vision further and actually acquires the technology and technical competencies to utilise this medium. The third competency is that of 'technical ability' and the last competency proposed is that of 'control'. This competency-based model implies that the owner-manager manages the Internet within the context of the overall business and marketing activities on a continuous basis (Durkin \& McGowan, 2001). Clearly, however, these steps would require a substantial commitment in terms of time by the owner-manager, and if this were not forthcoming, it would compromise the effective implementation of an information system such as the Internet (Cragg \& King, 1993).

McGowan et al. (2001), attempted to test the model developed by Durkin and McGowan (2001), by conducting 25 in-depth interviews with small business entrepreneurs who used the Internet. The study was conducted across a number of different sectors within the context of using the Internet to manage buyer-seller relationships. The results confirmed the importance of the involvement of the ownermanager in the everyday management of Internet marketing (as did the research of McGowan and Durkin, 2002). These findings are supported by the earlier research by Delone (1988), in respect of information technology, which found that where computers are onsite, availability is correlated with their successful use. It was argued that the reason for this was that where the computers were on the premises, as opposed to in a remote location, they triggered management involvement in their use. In small businesses, it is not uncommon that only the owner-manager has access to information and resources to make and implement appropriate decisions (O'Toole, 2003) and this finding is particularly germane to small tourism businesses because of the inseparability of production and consumption (Palmer, 2001).

Thus, we suggest that owner-manager involvement in the use of the Internet as a marketing tool will enhance the probability of successful Internet marketing in small tourism organisations.

\section{Methodology}

\section{The measuring instrument}

In order to enhance the validity and reliability of the results, measuring instruments from previous studies were, where possible, used to measure both the independent variables and the dependent variable. There are, however, few reliable scales to measure most of the aspects of e-business ( $\mathrm{Wu}$, Mahajan \& Balasubramanian, 2003). Where instruments were inadequate or unavailable, additional questions were formulated, based on the literature, to ensure that each variable was measured by at least five items. All the items in the questionnaire were linked to a 7-point Likert-type scale where 7 was labelled 'strongly agree' and 1 'strongly disagree'.

\section{The sample}

Despite the importance of tourism in creating employment and generally growing the economy in South Africa, there is no comprehensive database of tourism operators in South Africa (Myles, 2003; Seymour, 2002). Although the various tourism authorities have databases of tourism businesses, these are not comprehensive as registration with these organisations is not mandatory.

The databases of tourism businesses registered with the Western Cape Tourism authority, KwaZulu-Natal Tourism authority and the Eastern Cape Tourism authority were obtained. In the case of the Eastern Cape database, this was supplemented by the databases of the tourism authorities of Buffalo City, Nelson Mandela Metropolis and the Wild Coast, as there was no integration between these various databases. These databases were used to elicit the contact details of those small tourism businesses with Web sites which were used as the qualifying criterion to define those tourism businesses which use the Internet to market their businesses. The population of this study was the databases of the various tourism authorities described above and is thus a convenience sample.

Altogether 2011 owners of small tourism businesses were surveyed and the 316 usable questionnaires returned comfortably exceed the minimum guideline for the use of multivariate statistical procedures to analyse the data (Hair, Anderson, Tatham, \& Black, 1998).

\section{Statistical procedures}

\section{Validity assessment}

The initial step in the data analysis was to assess the discriminant validity of the instrument used to measure the variables in the theoretical model. This was done using the multivariate technique of exploratory factor analysis with the purpose of establishing which of the items measure each construct (and only that construct) in the theoretical model. The exploratory factor analysis was done using the computer programme BMDP4M (Frane, Jennrich \& Sampson, 1992). Maximum likelihood was used as the method of factor extraction and a direct quartimin oblique rotation was specified (Jennrich \& Sampson, 1996).

Initially the number of factors to be extracted was not specified. The eigen values in combination with the scree test suggested however, that the extraction of seven variables would be appropriate.

These factors were identified by an iterative process, deleting items that either did not load higher than 0.35 on any factor or alternatively loaded more than 0.35 or higher on two or more factors (cross-loading). The most interpretable factor structure to emerge from this iterative process is the one depicted in Table 1.

\section{Reliability of the measuring instrument}

Reliability refers to the extent to which measures or data are free from error and thus yield consistent, reproducible 
results. The reliability of an instrument thus depends on how much of the variation in scores is attributable to random errors (Churchill, 1979). Reliability is thus the consistency or stability of empirical indicators from measurement to measurement (Parasuraman, 1991). If the association between the different items is high, they are consistent in giving the same results and therefore reliable (Parasuraman, 1991).

One way of measuring reliability is using Cronbach's alpha coefficient, which is based on the average correlation of items within a test, and is regarded as an indication of internal consistency.

\section{Results}

\section{Discriminant validity results}

The factor matrix shown in Table 1 shows that after four iterations 22 items loaded on seven distinct factors, explaining a total of 70 percent of the variance in the data. The seven factors in Table 1 are named Product champion, Owner-manager knowledge, Alliances, Links, Ownermanager decision-making, Owner-manager involvement and Owner-manager vision.

In this study, the construct Product champion is defined as the degree to which the owner-manager appreciates what the Internet can do for the marketing of the business and is excited, passionate, enthusiastic and committed to its use in the marketing of the firm. The original instrument used six items (PC1, PC2, PC3, PC4, PC5 and PC7) to measure Product champion. Four items (PC1, PC2, PC3 and PC4) loaded on a single factor as expected together with one additional item (TK1). This item refers to the appreciation by the owner-manager of what the Internet can do for the marketing of the business and was regarded as an additional measure of the Product champion variable.

Factor 2 was labelled Owner-manager and comprised four items (TK2, TK3 TK4 and TK5) of the six items expected to measure the construct. One item expected to measure owner involvement (OI4) loaded on this factor as well, which was regarded as an additional measurement of the Ownermanger knowledge variable as it refers to the ownermanager monitoring the progress of Internet marketing which, we argue, would be implicit in appreciating the business issues surrounding the firm's use of the Internet for marketing.

The construct of Owner-manager knowledge is defined as the extent to which the owner-manager of a small tourism business appreciates, monitors and understands the business implications of the Internet, which allows him to make informed decisions about the use of the Internet for marketing purposes.
Alliances was the name given to Factor 3. In this study, Alliances refer to the extent to which small tourism businesses use contact networks as a resource to plan and implement their Internet marketing strategy. Six items were used to measure the construct Alliances of which four loaded on one factor, as expected. Two items (ALI1 and ALI6) did not load on any factor and were deleted.

Trust for the purposes in this study is defined as the extent to which small tourism businesses secure the integrity of their consumers' data and restrict the secondary use of the data, have links to their Web site from other reputable tourism organisations, fulfil their online obligations and keep their Web site updated. The exploratory factor analysis results revealed that the items expected to measure Trust did not load on a separate factor as expected. The exceptions are two items (TRU5 and TRU6 which loaded on a single factor) referring to links from other tourism Web sites and was subsequently named Links (Factor 4). The variable Links was operationalised as the extent to which there are links to the small businesses Web site from other tourism businesses Web sites.

Six items (OI1, OI2, OI3, OI4, OI5 and OI6) were originally used to measure the construct Owner-manager involvement. The exploratory factor analysis results revealed however, that this construct consists of two underlying dimensions. Two of these items (OI2 and OI3) loaded on one factor (Factor 5) with a further two items (OI5 and OI6) loading on Factor 6. Factor 5 was named Owner-manager decisionmaking and is operationalised as the extent to which the owner-managers are involved and participate in decision making about the Internet marketing of their businesses. In contrast, Factor 6 was named Owner-manager involvement and is operationalised as the extent to which the ownermanager is involved in the everyday managing of the small tourism businesses' Internet marketing initiative.

A new factor emerged from the factor analysis consisting of items expected to measure the constructs of Owner-manager knowledge (TK6) and Product champion (PC7). Both items allude to the vision of the Owner-manager in respect of the potential of the Internet for the marketing of their businesses and this factor is accordingly named Owner-manager vision. This construct is operationalised as the extent to which the owner-managers of small tourism businesses are aware of the potential of Internet marketing and believe that it can add value to their business.

The results of the exploratory factor analysis revealed that the independent variables in this study have demonstrated sufficient discriminant validity. Table 1 shows seven distinct underlying factors that are not only interpretable but each item measures only one underlying construct. These seven factors or variables were regarded as the independent variables impacting on the dependant variable Perceived success of Internet marketing. 
Table 1: Exploratory factor analysis results

\begin{tabular}{|c|c|c|c|c|c|c|c|}
\hline Item & $\begin{array}{c}\text { Factor } 1 \\
\text { Product } \\
\text { champion }\end{array}$ & $\begin{array}{c}\text { Factor } 2 \\
\text { Owner- } \\
\text { manager } \\
\text { knowledge }\end{array}$ & $\begin{array}{l}\text { Factor } 3 \\
\text { Alliances }\end{array}$ & $\begin{array}{c}\text { Factor } 4 \\
\text { Links }\end{array}$ & $\begin{array}{c}\text { Factor } 5 \\
\text { Owner- } \\
\text { manager } \\
\text { decision } \\
\text { making }\end{array}$ & $\begin{array}{c}\text { Factor } 6 \\
\text { Owner- } \\
\text { manager } \\
\text { involvement }\end{array}$ & $\begin{array}{c}\text { Factor } 7 \\
\text { Owner- } \\
\text { manager } \\
\text { vision }\end{array}$ \\
\hline PC1 & 0,902 & $-0,042$ & 0,025 & 0,011 & $-0,019$ & 0,040 & $-0,016$ \\
\hline PC2 & 0,835 & 0,003 & 0,017 & 0,034 & $-0,002$ & $-0,010$ & 0,065 \\
\hline TK1 & 0,793 & 0,035 & $-0,033$ & $-0,051$ & 0,029 & 0,057 & 0,035 \\
\hline PC4 & 0,667 & 0,172 & 0,050 & 0,044 & $-0,038$ & 0,028 & 0,016 \\
\hline PC3 & 0,554 & 0,084 & 0,084 & $-0,081$ & 0,250 & 0,000 & 0,064 \\
\hline TK4 & 0,006 & 0,881 & $-0,005$ & $-0,034$ & 0,067 & $-0,001$ & 0,050 \\
\hline TK3 & 0,011 & 0,785 & 0,005 & 0,045 & $-0,007$ & 0,007 & 0,099 \\
\hline TK5 & 0,059 & 0,670 & 0,051 & 0,041 & $-0,086$ & 0,195 & 0,048 \\
\hline TK2 & 0,136 & 0,609 & 0,035 & 0,072 & 0,158 & 0,031 & $-0,116$ \\
\hline OI4 & 0,062 & 0,429 & 0,132 & 0,139 & 0,004 & 0,199 & $-0,031$ \\
\hline ALI3 & 0,020 & $-0,027$ & 0,763 & 0,042 & $-0,015$ & $-0,028$ & $-0,001$ \\
\hline ALI4 & 0,029 & $-0,083$ & 0,708 & 0,036 & 0,015 & 0,081 & $-0,020$ \\
\hline ALI2 & $-0,070$ & 0,154 & 0,673 & $-0,118$ & 0,000 & $-0,017$ & 0,045 \\
\hline ALI5 & 0,138 & 0,025 & 0,416 & 0,108 & 0,046 & $-0,012$ & 0,050 \\
\hline TRU6 & $-0,037$ & 0,036 & 0,090 & 0,991 & $-0,021$ & $-0,012$ & $-0,058$ \\
\hline TRU5 & 0,001 & 0,009 & $-0,062$ & 0,667 & 0,038 & 0,007 & 0,066 \\
\hline OI3 & $-0,060$ & $-0,001$ & $-0,005$ & $-0,001$ & 0,875 & 0,034 & 0,025 \\
\hline OI2 & 0,099 & 0,052 & 0,026 & 0,048 & 0,675 & 0,032 & 0,018 \\
\hline OI5 & 0,009 & 0,020 & $-0,022$ & $-0,034$ & 0,098 & 0,929 & $-0,013$ \\
\hline OI6 & 0,087 & 0,120 & 0,092 & 0,086 & $-0,070$ & 0,566 & 0,170 \\
\hline TK6 & 0,032 & 0,042 & 0,050 & 0,041 & 0,037 & 0,051 & 0,889 \\
\hline PC7 & 0,344 & $-0,001$ & $-0,010$ & 0,027 & 0,151 & 0,055 & 0,392 \\
\hline Eigen-Values & 10,283 & 1,923 & 1,522 & 1,269 & 0,990 & 0,680 & 0,625 \\
\hline
\end{tabular}

\section{Reliability results}

All of the factors identified in Table 2 returned a Cronbach alpha coefficient score in excess of 0.70 and are accordingly considered reliable.

\section{Table 2: Cronbach alpha coefficients}

\begin{tabular}{l|c}
\hline \multicolumn{1}{c|}{ Factor } & Cronbach Alpha \\
\hline Factor: 1: Product Champion & 0.928 \\
\hline Factor: 2: Owner-manager knowledge & 0.915 \\
\hline Factor: 3 Alliances & 0.767 \\
\hline Factor: 4: Links & 0.800 \\
\hline Factor: 5: Owner-manager decision making & 0.810 \\
\hline Factor: 6: Owner-manager involvement & 0.850 \\
\hline Factor: 7: Owner-manager vision & 0.849
\end{tabular}

The dependent variable: Perceived success of Internet marketing

The multidimensional nature of marketing and business performance suggests that no individual measure will be adequate to measure these nebulous concepts. In view of the diverse range of measures for the success of Internet marketing, the items measuring the Perceived success of Internet marketing were not subjected to a factor analysis as it was not anticipated that they will load on a single variable. Ten items (derived from the literature and preliminary qualitative research) were formulated to measure the dependent variable of the Perceived success of Internet marketing.

Table 3 shows, however, that the items used to measure the dependent variable demonstrated an exceptional level of reliability $(\alpha=0.915)$.

\section{The hypotheses}

Following the validity and reliability assessments the following hypotheses were empirically tested:

$\mathrm{H}^{1}$ : There is a positive relationship between the ownermanager being a product champion in respect of marketing over the Internet and the perceived success of Internet marketing

$\mathrm{H}^{2}$ : There is a positive relationship between the extent of the owner-manager's knowledge of the business implications of marketing over the Internet and the perceived success of Internet marketing

$\mathrm{H}^{3}$ : There is a positive relationship between the existence of alliances and the perceived success of Internet marketing

$\mathrm{H}^{4}$ : There is a positive relationship between the existence of links and the perceived success of Internet marketing 
$\mathrm{H}^{5}$ : There is a positive relationship between the participation of the owner-manager in decision making about Internet marketing and the perceived success of Internet marketing

$\mathrm{H}^{6}$ : There is a positive relationship between the ownermanager's involvement in the management of Internet marketing and the perceived success of Internet marketing

$\mathrm{H}^{7}$ : There is a positive relationship between the ownermanager's vision about the potential of Internet marketing and the perceived success of Internet marketing

To test these hypotheses a multiple regression analysis was conducted.

\section{Multiple regression analysis results}

The multiple regression analysis results with the seven factors shown in Table 1 as independent variables and
Perceived success of Internet marketing as dependent variable are shown in Table 4.

It is apparent from Table 4 that four of the independent variables namely Product champion, Alliances, Ownermanager involvement and Owner-manager vision, exert a positive influence over the dependent variable Perceived success of Internet marketing. Table 4 also shows that the independent variables in the multiple regression analysis explain 61.7 percent of the variance in the dependent variable Perceived success of Internet marketing.

\section{Product champion}

It is apparent from Table 4 that the relationship between Product champion and the Perceived success of Internet marketing (hypothesis $\left.\mathrm{H}^{1}\right)$ is significant $(\mathrm{p}<0.001)$. This result suggests that, where the owner-manager acts as product champion in respect of Internet marketing in small tourism businesses, this initiative will be more likely to be successful. It follows that $\mathrm{H}^{1}$ is accepted.

\section{Table 3: Reliability assessment: Perceived success of internet marketing}

\begin{tabular}{|c|c|c|}
\hline Question & Item-Total correlation & $\begin{array}{l}\text { Cronbach alpha } \\
\text { after deletion }\end{array}$ \\
\hline I am satisfied that Internet marketing reduces our marketing costs & 0,517 & 0,917 \\
\hline $\begin{array}{l}\text { I am satisfied that the use of the Internet for marketing results in increased bookings for our } \\
\text { business }\end{array}$ & 0,733 & 0,904 \\
\hline I am satisfied that our Web site assists us in getting referrals (word of mouth) & 0,679 & 0,907 \\
\hline I am satisfied that the Internet assists us in maintaining relationships with existing customers & 0,616 & 0,911 \\
\hline I am satisfied that use of the Internet for marketing assists us in getting repeat business & 0,742 & 0,904 \\
\hline $\begin{array}{l}\text { I am satisfied that the Internet improves our ability to find out information about customers, } \\
\text { competitors and the tourism industry }\end{array}$ & 0,621 & 0,911 \\
\hline I am satisfied that use of the Internet improves the image of our business & 0,719 & 0,905 \\
\hline $\begin{array}{l}\text { I am satisfied that use of the Internet improves the effectiveness of advertising and promoting our } \\
\text { business }\end{array}$ & 0,824 & 0,899 \\
\hline I am satisfied that the Internet enhances our customer service & 0,754 & 0,903 \\
\hline $\begin{array}{l}\text { I am satisfied that the Internet assists us in conveying information about our business to } \\
\text { customers }\end{array}$ & 0,672 & 0,908 \\
\hline
\end{tabular}

Table 4: Multiple regression results

Dependent variable: Successful internet marketing

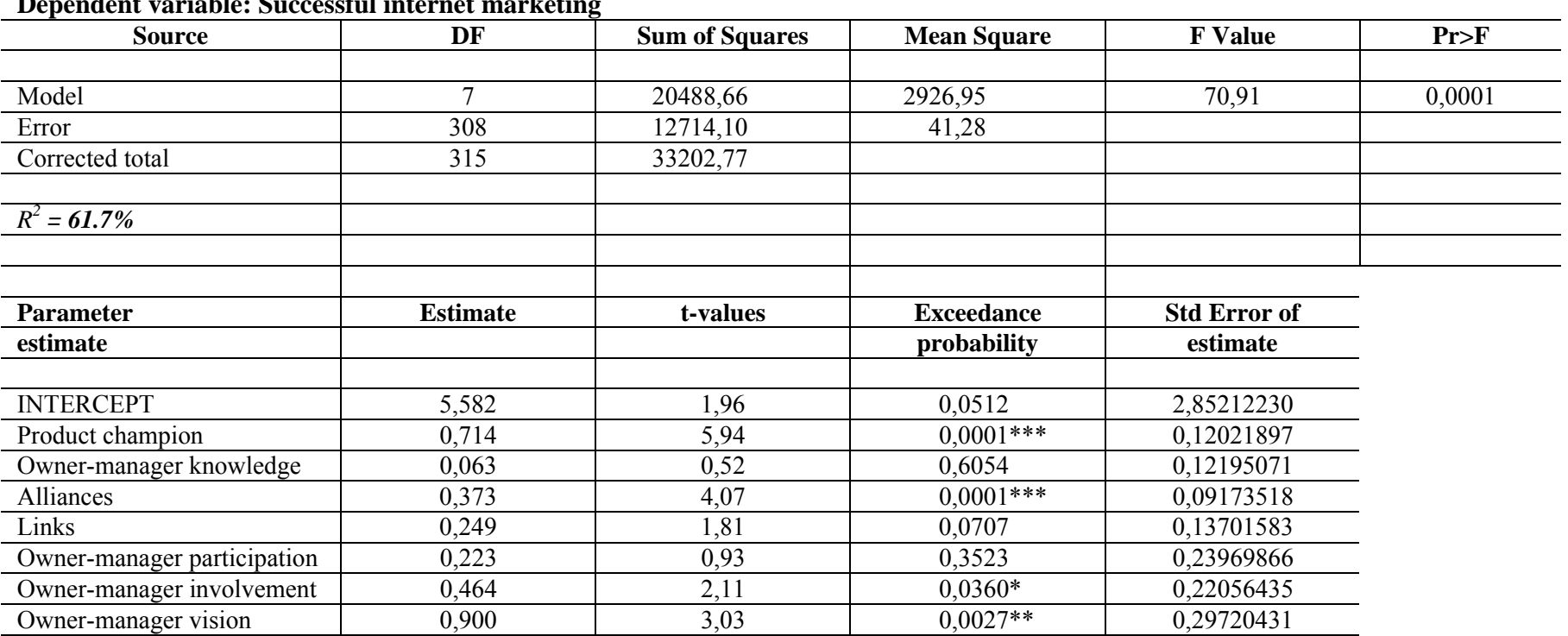

$$
\begin{aligned}
& *=\mathrm{p}<0,05 \\
& * *=\mathrm{p}<0,01 \\
& * * *=\mathrm{p}<0,001
\end{aligned}
$$


This result is consistent with the argument that the use of the Internet can be regarded as an innovation (Bengtsson, Boter \& Vanyushyn, 2003; Mehrtens, Cragg \& Mills, 2001) and that, in respect of the successful adoption and implementation of innovations, a product champion is important (Cragg \& King, 1993; Ettlie, Bridges \& O'Keefe, 1984). In addition, the significance of the owner-manager acting in the role of product champion is also consistent with past research with regard to the importance of a product champion in successfully utilising the Internet for marketing (Bengtsson, Boter \& Vanyushyn, 2003; Mehrtens, Cragg \& Mills, 2001; Stansfield \& Grant, 2003; Thong \& Yap, 1995).

\section{Owner-manager knowledge}

No empirical support was found for the hypothesised relationship between Owner-manager knowledge and Perceived success of Internet marketing (hypothesis $\mathrm{H}^{2}$ ). Whether the owner-manager appreciates the business potential of the Internet or not will therefore have no direct impact on the success of the Internet marketing of a small tourism business. Hypothesis $\mathrm{H}^{2}$ is accordingly rejected.

This finding is inconsistent with research in respect of information systems (for example Cragg \& King, 1993; Thong \& Yap, 1995), which found that while ownermanagers did not need to be experts in information technology, a reasonable level of technical knowledge is important for its successful adoption and implementation. However, these findings (Cragg \& King, 1993; Thong \& Yap, 1995) can be distinguished from the research in respect of the use of Internet for marketing, which emphasised the importance of the owner-manager appreciating and understanding the broader business implications of the Internet for marketing, in order to coordinate this medium to achieve marketing goals, as opposed to an understanding of the technology per se. Nevertheless, the empirical findings in this study contradict the research in respect of the importance of the owner-manager's grasp of the business implications of the use of the Internet for marketing purposes (Mehrtens, Cragg \& Mills, 2001; McGowan \& Durkin, 2002).

\section{Alliances}

Hypothesis $\mathrm{H}^{3}$ is accepted as the current study revealed a significant relationship $(\mathrm{p}<0.001)$ between Alliances and the Perceived success of Internet marketing. In other words, the more the owner-manager makes use of alliances as a resource to plan and implement the use of the Internet for marketing, the more likely that the Internet marketing of the business will be successful. One reason for this relationship is that small firms usually suffer from a lack of resources, and networks expand the resources of small businesses (Hoffman \& Novak, 1997; McGowan \& Durkin, 2002; McGowan et al., 2001; Rayport \& Jaworski, 2001), which is critical to the success of Internet marketing. In addition, alliances may add value in terms of developing new products and ways of marketing products, using the Internet (Hoffman \& Novak, 1997; Gilmore, Carson \& Grant, 2001; Jones, Hecker \& Holland, 2003; Rayport \& Jaworski, 2001).

\section{Links}

Although trust in the online world is understood to mean security and privacy, and these aspects are at the core of Internet marketing, it was not possible to measure the impression of consumers in this regard. Rather, trust, in this study, is defined as the steps that a business can take to engender trust and this could be by setting up links with other similar or complementary Web sites. These links can be interpreted as a form of third party reference or cobranding (Durkan, Durkin \& Gillen, 2003; McCole, 2002; Urban, Sultan \& Qualls, 2000). Although Table 4 shows that Hypothesis $\mathrm{H}^{4}$ must be rejected at the 5 percent level of significance, the exceedance probability of 0.0707 shows that the relationship between Links and the Perceived success of Internet marketing approaches significance and is at least positive as expected.

\section{Owner-manager decision-making}

It is apparent from Table 4 that Owner-manager decisionmaking has no significant influence on the Perceived success of Internet marketing and hypothesis $\mathrm{H}^{5}$ is accordingly rejected. This means that the involvement of the owner-manager in the decision making in regard to Internet marketing will not have an impact on the success of Internet marketing.

The empirical findings in this study, contradict previous research that emphasised the importance of owner-manager involvement in decision making in regard to Internet marketing. The rationale behind these earlier findings is that in small businesses, only the owner-manager usually has access to the information and resources necessary to make and implement appropriate decisions (McGowan \& Durkin, 2002; McGowan et al., 2001; O’Toole, 2003).

\section{Owner-manager involvement}

It is apparent from Table 4 that there is a significant positive relationship Owner-manager involvement and the Perceived success of Internet marketing at the 5 percent level. In other words, Hypothesis $\mathrm{H}^{6}$ is accepted as there is support for the assertion that Owner-manager involvement has a positive influence on the Perceived success of Internet marketing. This indicates that the success of Internet marketing is influenced by the involvement of the owner-manager in the day-to-day management of the Internet for marketing. This implies that it is not satisfactory for the owner-manager to delegate this task to someone else, either inside or outside the business as this may compromise the success of Internet marketing. This result is consistent with previous research that emphasised the importance of the involvement of the owner-manager in the use of the Internet for marketing purposes (Cragg \& King, 1993; Delone, 1988; Durkin \& McGowan, 2001; McGowan \& Durkin, 2002; McGowan et al., 2001).

\section{Owner-manager vision}

Hypothesis $\mathrm{H}^{7}$ is accepted as the current study revealed a significant positive relationship at the 1 percent level between Owner-manager vision and the Perceived success 
of Internet marketing. This dimension relates to the appreciation or understanding, by the owner-manager, of what the Internet can accomplish in the marketing of a small tourism business.

This finding is in line with research which has shown that the vision of the owner-manager of the use of the Internet is an important phase in achieving Internet marketing success (Durkin \& McGowan, 2001; McGowan \& Durkin, 2002; McGowan et al., 2001).

\section{Managerial implications for small tourism businesses}

The literature overwhelmingly concurs with the findings of this study on the significance of a product champion on the successful implementation of the Internet for marketing. The excitement, enthusiasm, passion and commitment with which the owner-manager embraces the use of the Internet for marketing, generates support for the project amongst employees of the business. This is particularly pertinent in high contact service businesses such as small tourism businesses where, given the inseparability of production and consumption, employees are an important part of the marketing communication process.

The empirical results proved that alliances are an important determinant of successful Internet marketing. The importance of alliances with competing or complementary organisations lies with not only in their ability to access knowledge resources for the owner-manager, but also with the opportunities they present in terms of creating new products and opportunities.

Small tourism businesses should not be too narrow in their approach to sourcing ideas and forming associations. Complementary businesses or service businesses not in the tourism sector may offer insights and notions that may not be established practice in a particular sub-sector of the tourism market and that may give a business some shortterm advantage in respect of its competitors with regard to Internet marketing. Similarly, businesses should maintain close links with regional tourism organisations as they frequently commission, or have access to research that may have a positive impact on the Internet marketing of small businesses.

The results confirm the significance of the owner-manager's involvement in the day-to-day managing of the tourism initiative as well as the importance the vision of the owner manager in respect of the promise of Internet marketing. This emphasises the point that simply implementing the Internet is no silver bullet. Successful implementation still requires a substantial contribution from the owner-manager as do most aspects of small business management. The reason for this is that in small businesses only the ownermanager has the vision and the authority to access and implement resources appropriately to ensure that the Internet marketing initiative is in congruence with the strategic direction of the small tourism business.

\section{References}

Arthur, B. W. 1996. 'Increasing returns and the new world of business', Harvard Business Review, 74(4):100-109.

Bengtsson, M., Boter, H. \& Vanyushyn, V. 2003. 'The challenge of building marketing channels via the Internet'. Paper presented at the International Council for Small Business (ICSB) 2003 Conference, 15-18th June 2003. Belfast, Northern Ireland.

Bennett, J. A. 2000. 'What is tourism?' In Bennett, J. A. (Ed.). Managing tourism services. $2^{\text {nd }}$ edition. Pretoria: J. L. Van Schaik Publishers.

Bhatnagar, A. \& Ghose, S. 2004. 'A latent class segmentation analysis of e-shoppers', Journal of Business Research, 57(7):758-767.

Carr, N. G. 2000. 'Hypermediation: Commerce as clickstream', Harvard Business Review, 78(1):46-47.

Carson, D. J., Cromie, S., McGowan, P. \& Hill, J. 1995. Marketing and entrepreneurship in SMEs: An innovative approach. London: Prentice Hall.

Carson, D. J., Gilmore, A., Cummins, D., O’Donnell, A. \& Grant, K. 1998. 'Price settings in SMEs: Some empirical findings', Journal of Product and Brand Management, 7(1):74-86.

Churchill, G. A. 1979. 'A paradigm for developing better measures for marketing constructs', Journal of Marketing Research, 16(1):64-73.

Clinton, W. J. \& Gore, A. 1997. A Framework for global electronic commerce. [online]

URL: http://www.iitf.nist.gov/eleccomm/ecomm htm\#no.1. Accessed 21 December 2001.

Collinson, E. \& Shaw, E. 2001. 'Entrepreneurial marketing A historical perspective on development and practice', Management Decision, 39(1):761-766.

Cragg, P. B. \& King, M. 1993. 'Small firm computing: Motivators and inhibitors', MIS Quarterly, 17(1):47-60.

Cragg, P. B. \& Zinatelli, N. 1995. 'The evolution of information systems in small firms', Information and Management, 29(1):1-8.

Dean, J. \& Holmes, S. 1997. 'Understanding business networks: Evidence from the manufacturing \& service secures in Australia', Journal of Small Business Management, 35(1):78-84.

DeLone, W. 1988. 'Determinants of success for computer usage in small business', MIS Quarterly, 12(1):51-61.

Donckels, R. \& Lambrecht, J. 1997. 'The network position of small businesses: An explanatory model', Journal of Small Business Management, 35(2):13-25. 
Durkan, P., Durkin, M. \& Gillen, J. 2003. 'Exploring efforts to engender on-line trust', International Journal of Entrepreneurial Behaviour \& Research, 9(3):93-110.

Durkin, M. \& McGowan, P. 2001. "Net Effect" - Views from the periphery: Exploring the role and importance of the internet on marketing activity in entrepreneurial firm', Irish Marketing Review, 14(1):15-25.

Elliott, R. M. 1997. 'The World Wide Web: Analysis of some South African sites through usage of the flow construct'. Unpublished MBA thesis, Graduate School of Business, University of Cape Town.

Ettlie, J. E., Bridges, W. P. \& O'Keefe, R. D. 1984. 'Organization strategy and structural differences for radical versus incremental innovation', Management Science, 30(6): 682-695.

Frane, J., Jennrich, R. I. \& Sampson, P. F. 1992. '4M factor analysis'. In Dixon, W. J. (Ed.). BMDP statistical software manual 1. Berkeley: University of California Press. Pp.329385 .

Gilmore, A., Carson, D. \& Grant, K. 2001. 'SME marketing in practice', Market Intelligence and Planning, 19(1):6-11.

Graham, P. G. 1999. 'Small business participation in the global economy', European Journal of Marketing, 33(1/2):88-102.

Hair, J. F., Anderson, R. E., Tatham, R. L. \& Black, W. C. 1998. Multivariate data analysis. $5^{\text {th }}$ edition. Englewood Cliffs, New Jersey: Prentice Hall.

Hart, C., Doherty, N. \& Ellis-Chadwick, F. 2000. 'Retailer adoption of the Internet - Implications for retail marketing', European Journal of Marketing, 34(8):954-974.

Haynes, P. J., Becherer, R. C. \& Helms, M. M. 1998. 'Small \& mid-sized businesses \& Internet use: Unrealised potential?', Internet Research: Electronic Networking Applications \& Policy, 8(3):229-235.

Hill, J. \& McGowan, P. 1996. 'Developing a networking competency for effective enterprise development', Journal of Small Business \& Enterprise Development, 3(3):148-57.

Hof, R. D. 2000. 'The tech slump', Business Week (European Edition). 18 December: 92-96.

Hoffman, D. L. \& Novak, T. P. 1996. 'Marketing in hypermedia computer-mediated environments: Conceptual foundations', Journal of Marketing, 60(3):50-68.

Hoffman, D. L. \& Novak, T. P. 1997. 'A new marketing paradigm for electronic commerce', The Information Society, 13(1):43-54.

Hoffman, D. L., Novak, T. P. \& Chatterjee, P. 1995. 'Commercial scenarios for the Web: Opportunities \& challenges', Journal of Computer-Mediated Communication, 1(3). [online] URL:http: //shum.huji.ac.il/jcmc/voll/ issue3 /hoffman.html. Accessed 7 November 2001.

Hoffman, D. L., Novak, T. P. \& Peralta, M. A. 1999. 'Building consumer trust online'. Communications of the ACM, 42(4):80-85.

Jennrich, R. I. \& Sampson, P. F. 1996. 'Rotation for simple loadings', Psychometrika, 31: 313-323.

Jones, C., Hecker, R. \& Holland, P. 2003. 'Small firm Internet adoption: Opportunities forgone, a journey not begun', Journal of Small Business and Enterprise Development, 10(3):287-297.

Kımıloğlu, H. 2004. 'The e-literature: A framework for understanding the accumulated knowledge about Internet', Marketing Academy of Marketing Science Review, 6: 1-36.

Kritzinger, H. L. \& Du Plessis, P. J. 2001. 'An exploratory study of the practice of relationship marketing by South African small to micro enterprises using the Internet as an enabler'. Paper presented at the Southern Africa Institute for Management Scientists (SAIMS) 2001 Conference, 9 - 11 September, Stellenbosch University, South Africa.

Lado, A.A., Boyd, N.G. \& Hanlon, S.C. 1997. 'Competition, cooperation and the search for economic rent: A syncretic model', Academy of Management Review, 22(1): 110-141.

Lado, A. A., Boyd, N. G. \& Wright, P. 1992. 'A competency-based model of sustainable competitive advantage: Toward a conceptual integration', Journal of Management, 18(1):77-91.

Larkin, K. \& Elliott, R. M. 2003. 'A study of the marketing practices used in some SMMEs: A qualitative approach'. Paper presented at the Southern Africa Institute for Management Scientists (SAIMS) 2003 Conference, 28 - 30 September. Potchefstoom University, Potchefstoom, South Africa.

Lee, K. S., Tan, S. J. \& Lim, G. H. 2000. 'E-retailing: Success factors for entrepreneurial start ups'. Paper presented at the International Council for Small Business (ICSB) 2000 Conference. 9 June, Brisbane, Australia.

Markham, S. K. \& Aiman-Smith, L. 2001. 'Product champions: Truths, myths and management', Research Technology Management, 44(3): 44-45

Marshall, P., Sor, R. \& McKay, J. 2000. 'An industry case study of the impacts of electronic commerce on car dealerships in Western Australia', Journal of Electronic Commerce Research, 1(1):1-16.

McCole, P. 2002. 'The role of trust for electronic commerce in services', International Journal of Contemporary Hospitality Management, 14(2):81-87.

McDermott, C. M. \& O'Connor, G. C. 2002. 'Managing radical innovation: An overview of emergent strategy 
issues', Journal of Product Innovation Management, 19: 424-438.

McGowan, P. \& Durkin, M. 2002. 'Toward an understanding of Internet adoption at the marketing/entrepreneurship interface', Journal of Marketing Management, 18(3/4): 361-377.

McGowan, P., Durkin, M., Allen, L., Dougan, C. \& Nixon, S. 2001. 'Developing competencies in the entrepreneurial small firm for use of the Internet in the management of customer relationships', Journal of European Industrial Training, 25(2/3/4):126-136.

Mehrtens, J., Cragg, P. B. \& Mills, A. M. 2001. 'A model of Internet adoption by SMEs', Information and Management, 39(3):165-176.

Middleton, V. T. C. \& Clarke, J. R. 2001. Marketing in travel and tourism. $3^{\text {rd }}$ edition. Oxford: ButterworthHeinemann.

http://weblinks2.epnet.com/ - bib69up

Morgan, R. M. \& Hunt, S. D. 1994. 'The commitment-trust theory of relationship marketing', Journal of Marketing, 58(3):20-38.

Myles, P. 2003. Personal communication. Tourism consultant, Port Elizabeth. 8 October.

Neveling, N. 2004. 'Where technology meets experience', Sunday Times Business Times, 22 February: 14.

Ntsika Enterprise Promotion Agency. 1998. State of small business in South Africa. Pretoria: Ntsika Enterprise Promotion Agency.

Ntsika Enterprise Promotion Agency. 2002. State of small business in South Africa. Pretoria: Ntsika Enterprise Promotion Agency.

O'Toole, T. 2003. 'E-relationships- emergence and small firms', Marketing Intelligence and Planning, 21(2):115-122.

Palmer, A. 2001. Principles of services marketing. $3^{\text {rd }}$ edition. Glasgow: McGraw-Hill.

Parasuraman, A. 1991. Marketing research. $2^{\text {nd }}$ edition. Reading: Addison-Wesley.

Piercy, N. F. \& Cravens, D. W. 1995. 'The network paradigm and the marketing organisation: Developing a new management agenda', European Journal of Marketing, 29(3):7-34.

Poon, S. \& Swatman, P. M. C. 1997. 'Small business use of the Internet: Findings from Australian case studies', International Marketing Review, 14(5):385-402.

Poon, S. \& Swatman, P. M. C. 1999. 'An exploratory study of small business Internet commerce issues', Information \& Management, 35(1):9-18.
Porter, M. E. 2001. 'Strategy and the Internet', Harvard Business Review, 79(3):63-78.

Rayport, J. F. \& Jaworski, B. J. 2001. E-commerce. New York: Irwin McGraw-Hill.

Rayport, J. F. \& Sviokla, J. J. 1995. 'Exploiting the virtual value chain', Harvard Business Review, 73(6):75-85.

Reichheld, F. F. \& Schefter, P. 2000. 'E-loyalty: Your secret weapon on the Web', Harvard Business Review, 78(4):105113.

Remenyi, D. 2000. 'E-biz-The great hunt for the golden fleece'. Paper presented at the Southern Africa Institute for Management Scientists (SAIMS) 2000 Conference, 31 October-2 November, University of South Africa, Midrand, South Africa.

Rogers, E. M. 1995. Diffusion of innovations. 4th edition. New York: Free Press.

Runge, D. A. \& Earl, M. 1988. 'Gaining competitive from telecommunications'. In Earl, M. (Ed.). Information management: The strategic dimension. Oxford: Clarendon Press, pp.125-146.

Seymour, J. 2002. Personal e-mail. Market Research and Information Systems Manager, Tourism KwaZulu-Natal, 25 April.

Shane, S. \& Venkataraman, S. 2000. 'The promise of entrepreneurship as a field of research', Academy of Management Review, 25(1):217-26.

South Africa. Department of Trade and Industry. 1995. White paper on the national strategy for the development and promotion of small business in South Africa. [online] URL:http:

//www.polity.org.za/govdocs/white_papers/smallbiz.html. Accessed 14 August 2001.

South Africa. Dept of Environmental Affairs and Tourism. 1996. White paper on the development and promotion of tourism in South Africa. Pretoria: Department of Environmental Affairs and Tourism.

South Africa. Department of Environmental Affairs and Tourism 1998. Tourism in gear: Tourism development strategy 1998-2000. Pretoria: Department of Environmental Affairs and Tourism.

Stansfield, M. \& Grant, K. 2003. 'An investigation into issues influencing the use of the Internet and electronic commerce among small-medium sized enterprises', Journal of Electronic Commerce Research, 4(1):15-33.

Thong, J. \& Yap, C. S. 1995. 'CEO characteristics, organisational characteristics, and information technology adoption in small business', Omega, 23(4):429-442. 
Turban, E., Lee, J., King, D. \& Chung, H. M. 2000. Electronic commerce - A managerial perspective. Upper Saddle River, New Jersey: Prentice-Hall.

United States. Small Business Administration. 2004. [online] URL: http: //www.sba.gov/. Accessed 11 October 2004.

Urban, G. L., Sultan, F. \& Qualls, W. J. 2000. 'Placing trust at the centre of your Internet strategy', Sloan Management Review, 24(1):39-48.

Vargha, R. \& Pettigrew, S. F. 2001. 'Internet issues for small and medium sized Australian Business'. In Chetty, S. $\&$ Collins, B. (Eds.). Proceedings of the Australian and New Zealand Marketing Academy (ANZMAC) Conference 2001, 1st - 5th December 2001, Massey University (Albany Campus), Auckland, New Zealand.

Venkatraman, N. 2000. 'Five steps to dot-com strategy: How to find your footing on the Web', Sloan Management Review, 41(3):15-28.

Weiber, R. \& Kollmann, T. 1998. 'Competitive advantages in virtual markets - perspectives of information-based marketing in cyberspace', The European Journal of Marketing, 32(7/8):603-615.

WTTC (World Travel and Tourism Council). 2002. South Africa: The impact of travel and tourism on jobs and the economy - 2002 plus special report on September $11^{\text {th }}$ impacts. London: World Travel and Tourism Council.

WTTC (World Travel and Tourism Council). 2003. South Africa: Travel \& tourism a world of opportunity. London: World Travel and Tourism Council.

Wu, F., Mahajan, V. \& Balasubramanian, S. 2003. 'An analysis of e-business adoption and its impact on business performance', Journal of the Academy of Marketing Science, 31(4):425 -447.

Yeung, J. H. Y., Shim, J. P. \& Lai, A. Y. K. 2003. 'Current progress of e-commerce adoption: Small and medium enterprises in Hong Kong', Communications of the ACM, 46(9):226-232. 


\section{ANNEXURE A}

PC1 I am excited about the use of the Internet for marketing our business

PC2 I am enthusiastic about the use of the Internet for marketing our business

TK1 I appreciate what the Internet can do for the marketing of our business

PC4 I am passionate about using the Internet for marketing our business

PC3 I am committed to using the Internet for marketing our business

TK4 I understand enough about Internet marketing to make informed decisions

TK3 I am knowledgeable about the use of the Internet for marketing

TK5 I know what is required to make the Internet effective for marketing

TK2 I understands the issues surrounding the use of the Internet for marketing

OI4 I closely monitors the progress of the Internet marketing of our business

ALI3 Our business associates improve our proficiency at obtaining information on how to market over the Internet.

ALI4 Our business associates' advice exerts an influence over the way our business markets over the Internet.

ALI2 We have strong associations with people who can assist us with advice on Internet marketing

ALI5 Informal networks are a source of information on Internet marketing

TRU6 There are links to our Web site from other well known tourism businesses

TRU5 There are links to our Web site from the regional and/or local tourism authority and/or other tourism businesses

OI3 Most decisions about the Internet marketing of our business are made by I

OI2 I am involved in decision-making about the Internet marketing of our business

OI5 I actively participate in managing the Internet for the marketing of our business

OI6 I make time to manage the Internet marketing of our business

TK6 I am aware of the potential of using the Internet for the marketing our business

PC7 I believe that the Internet can add value to the marketing of our business 